\title{
Soil compaction on traffic lane due to soil tillage and sugarcane mechanical harvesting
} operations

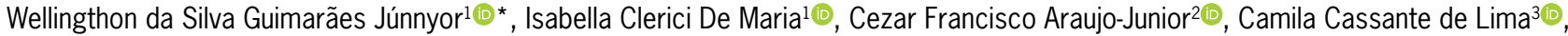 \\ André César Vitti^®${ }^{\oplus}$, Getulio Coutinho Figueiredo ${ }^{5}$, Sonia Carmela Falci Dechen ${ }^{1 \odot}$
}

Instituto Agronômico de Campinas/Centro de Solos e Recursos Ambientais, Av. Barão de Itapura, 1481 - 13012970 - Campinas, SP - Brasil.

2Instituto Agronômico do Paraná/ASO, Rod. Celso Garcia Cid, km 375 - 86047-902 - Londrina, PR - Brasil.

Universidade de São Paulo/ESALQ - Depto. de Ciência do Solo, Av. Pádua Dias, 11 - 13418-900 - Piracicaba, SP Brasil.

${ }^{4}$ Agência Paulista de Tecnologia dos Agronegócios - Polo Regional Centro Sul, Rod. SP 127, km 30 - 13400-970 Piracicaba, SP - Brasil.

5Universidade Federal do Rio Grande do Sul/FA - Depto. de Solos, Av. Bento Gonçalves, 7712 - 91501-970 - Porto

Alegre, RS - Brasil.

*Corresponding author <wellingthon.agro@gmail.com>

Edited by: Paulo Cesar Sentelhas

Received February 25, 2018

Accepted May 20, 2018
ABSTRACT: Mechanical sugarcane harvesting increases soil compaction due to the intense traffic of agricultural machinery, reducing longevity of sugarcane crops. In order to mitigate the harmful effects caused by agricultural traffic on the soil structure in sugarcane fields, this study evaluated impacts of mechanical sugarcane harvesting on traffic lane under two soil tillage systems based on load bearing capacity models. The experiment was carried out in the region of Piracicaba, state of São Paulo, Brazil, on a Rhodic Nitisol, under conventional tillage (CT) and deep strip-tillage (DST). For CT soil tillage was applied to the entire area with a heavy disk harrow, at operating depths from 0.20 to $0.30 \mathrm{~m}$ followed by a leveling harrow at a depth of $0.15 \mathrm{~m}$. For DST, soil tillage was performed in part of the area at a depth of $0.80 \mathrm{~m}$, forming strip beds for sugarcane planting, while the traffic lanes were not disturbed. Undisturbed soil samples from traffic lanes were used in the uniaxial compression test to quantify preconsolidation pressure and to model the soil load bearing capacity. The surface layer $(0.00-0.10 \mathrm{~m})$ was most susceptible to compaction, regardless of the tillage system (CT or DST) used. In the DST, the traffic lane maintained the previous soil stress history and presented higher load bearing capacity (LBC) than the traffic lane in the CT. As in CT the soil was tilled, the stress history was discontinued. This larger LBC in DTS minimized the impacts of the sugarcane harvest. Under CT, additional soil compaction due to mechanical sugarcane harvesting in the traffic lane was observed after the second sugarcane harvest. There was a reduction in load bearing capacity from $165 \mathrm{kPa}$ to 68 $\mathrm{kPa}$ under $\mathrm{CT}$ and from $230 \mathrm{kPa}$ to $108 \mathrm{kPa}$ under DST, from the first to the second harvest at surface layer. Water content at mechanical harvesting was the most relevant factor to maximize impacts on the soil structure in traffic lanes, for both tillage systems.

Keywords: load bearing capacity, soil stress distribution, preconsolidation pressure, modeling, environmental sustainability

\section{Introduction}

Brazil is the world's largest sugarcane producer, with 633 million tons harvested in the 2017/2018 season, in an area of 9 million ha. The southeastern region accounts for $62 \%$ of the total cane area harvested in Brazil, $84 \%$ of which in the state of São Paulo (CONAB, 2018).

Mechanical sugarcane harvesting in Brazil has intensified in recent years, in compliance with the ordinance to discontinue the burning for husking and, consequently, manual harvesting. This expansion resulted in the implementation of other machinery-based technologies intensifying traffic in mechanical harvesting and transportation (Souza et al., 2014; Lozano et al., 2013).

The intensive traffic of agricultural machinery has increased soil compaction, resulting in an unfavorable environment for crop development (Vischi Filho et al., 2015; Sousa et al., 2017) and reducing soil production capacity (Reichert et al., 2009).

For predictions of soil compaction behavior, data on preconsolidation pressure $\left(\sigma_{p}\right)$ are important for rational soil management (Severiano et al., 2010; Vischi Filho et al., 2015). The load bearing capac- ity model (LBCM), developed by Dias Junior and Pierce (1995), predicts the maximum pressure a soil can withstand at different moisture levels, without generating additional compaction. This maximum pressure is influenced by the historical date on soil use and, in particular, by the most recent soil tillage operations (Oliveira et al., 2003). Intensive tilling of soil surface layer, reducing density, breaking aggregates and relieving previously applied pressures, reduces soil bearing capacity. LBCM allows monitoring whether mechanical agricultural operations, such as harvesting operation, applied in a particular tillage system, are causing additional compaction of the soil.

Therefore, LBCM have been used to predict the pressure levels that can be applied into the soils for different water contents without additional compaction and for quantifying the effects of agricultural operations on the soil structure.

To reduce the effects caused by agricultural traffic on soil structure in sugarcane crops, this study assessed the impacts of mechanical sugarcane harvesting on two soil tillage systems under traffic lane, at two harvests (cane planting and first ratoon), using load bearing capacity models (LBCM). 


\section{Materials and Methods}

\section{Site location}

The experiment was carried out in Piracicaba (state of São Paulo) (22 $41^{\prime} 04^{\prime \prime} \mathrm{S} / 47^{\circ} 38^{\prime} 52^{\prime \prime}$ W; 554 m altitude). The climate of the region was classified as subtropical with dry winters (reaching temperatures below 18 ${ }^{\circ} \mathrm{C}$ ) and hot summers (with temperatures above $22^{\circ} \mathrm{C}$ ), (Cwa) according to the Köppen classification (Alvares et al., 2013), with an average annual temperature $21.6^{\circ} \mathrm{C}$ and an average rainfall 1,328 $\mathrm{mm}$ (CEPAGRI, 2018).

The soil of the study site was classified as Rhodic Nitisol, according to the World Reference Base of Soil Resources system (IUSS Working Group, 2015), with a blocky structure and shiny, characterizing a nitic B horizon overlying a latossolic B horizon, with a clay texture, containing 45, 45, 58 and $62 \%$ clay, 45, 45, 32 and $29 \%$ total sand and $2.71,2.71,2.72$ and $2.72 \mathrm{~kg} \mathrm{dm}^{-3}$ particle density at layers $0.00-0.10,0.10-0.20,0.20-0.40$ and $0.40-$ $0.60 \mathrm{~m}$, respectively.

\section{Experiment description}

In July 2013, when cane fields were replanted, the sites were subjected to the following treatments: conventional tillage $(\mathrm{CT})$ and deep strip-tillage (DST).

For conventional tillage (CT), $2 \mathrm{Mg}^{\mathrm{ha}} \mathrm{H}^{-1}$ of dolomitic limestone was applied on the entire area one day before planting and incorporated into the soil using a heavy disk harrow, with 24-inch disc harrow blades, at operating depths from 0.20 to $0.30 \mathrm{~m}$. It was applied 0.8 $\mathrm{Mg} \mathrm{ha} \mathrm{h}^{-1}$ gypsum on the day of planting, incorporated into the soil with a leveling harrow at a depth of $0.15 \mathrm{~m}$. All implements used for soil tillage were dragged by a tractor with front wheel drive and $77 \mathrm{~kW}$ (Table 1).

For the treatment of deep strip-tillage (DST), 2.8 $\mathrm{Mg} \mathrm{ha}{ }^{-1}$ dolomitic limestone $\left(2\right.$ and $0.8 \mathrm{Mg} \mathrm{ha}^{-1}$, at a depth of $0.40 \mathrm{~m}$ and $0.80 \mathrm{~m}$, respectively) was applied with a device that has a coupling system with the tractor drawbar, consisting of subsoiling one shank for deep subsoiling $(0.80 \mathrm{~m})$, a limestone application mechanism

Table 1 - Technical data of machines and equipment used in the experiment.

\begin{tabular}{|c|c|c|c|c|}
\hline $\begin{array}{l}\text { Machines and } \\
\text { equipment }\end{array}$ & $\frac{\text { Total Load }^{\text {a }}}{\text { kN }}$ & Axle & Tyres & $\frac{\text { Inflation Pressure }}{\mathrm{kPa}}$ \\
\hline \multirow{2}{*}{ Tractor - $77 \mathrm{~kW}$} & \multirow{2}{*}{53.2} & Front & $14.9-24$ & 103 \\
\hline & & Rear & $18.4-34$ & 92 \\
\hline \multirow{2}{*}{ Tractor - 201 kW } & \multirow{2}{*}{113.9} & Front & $600 / 60-30.5$ & 132 \\
\hline & & Rear & $850 / 60-38$ & 87 \\
\hline DST Equipment* & 17.6 & - & - & - \\
\hline \multirow{2}{*}{ Tractor - $139 \mathrm{~kW}$} & \multirow{2}{*}{92.9} & Front & $18.4-26$ & 155 \\
\hline & & Rear & $24.5-32$ & 83 \\
\hline Trailer & $201.0^{+}$ & Tandem & $600 / 50-22.5$ & 280 \\
\hline Harvester - 263 kW & 179.5 & Track $^{\circ}$ & 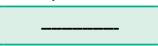 & - \\
\hline
\end{tabular}

and fertilizer application mechanism with two options of application depth $(0.40$ and $0.80 \mathrm{~m})$, with a rotary tiller with 16 blades that plow and disrupt the soil surface (0.00-0.40 m), forming the beds for planting. Limestone was applied along the bands inside the beds formed by the device. Deep strip-tillage was performed on July 15 , 2013 at an average working speed of $5 \mathrm{~km} / \mathrm{h}$, only in the planting row. The DST equipment was drawn by a tractor with $201 \mathrm{~kW}$ (Table 1). The use of this soil tillage system was due to the canteirization technique in sugarcane is an alternative to traffic control in sugarcane crops and has been widely used in sugarcane agroecosystems in the state of São Paulo. In this system (deep strip-tillage), soil tillage is performed across only a part of the area, forming beds for sugarcane plantings, which are subsequently protected from machinery, while traffic lanes are not disturbed.

The soil was tilled using a tractor with $134 \mathrm{~kW}$ (Table 1), pulling a furrow opener of São Francisco model. This implement is composed by two furrow openers. Sugarcane cultivar IAC-SP-95-5000 was planted manually in double spacing rows $(0.90 \times 1.50 \mathrm{~m})$ (Figure 1$)$. Topdressing consisted of $0.6 \mathrm{Mg} \mathrm{ha}^{-1}$ of the N-P-K fertilizer mixture 5-20-20 applied in the planting furrows based on the soil analysis performed prior to the experiment. Each experimental plot covered an area of 1,000 $\mathrm{m}^{2}(50 \times 20 \mathrm{~m})$.

\section{Soil sampling}

Soil samples with undisturbed structure were collected from the agricultural traffic lane before sugarcane harvesting, at four sampling points per experimental plot, along a diagonal line. For each plot, 20 undisturbed samples were collected from the center of the layers (0.00-0.10, 0.10-0.20, 0.20-0.40 and 0.40-0.60 m) (Figure 1 ), totaling 160 samples (20 samples $\times 4$ layers $\times 2$ soil tillage systems), with an Uhland sampler and stainless steel cylinders (diameter $69 \mathrm{~mm}$, height $25 \mathrm{~mm}$ ).

\section{Soil analysis}

The particle size analysis was performed using the pipette method (Gee and Bauder, 1986). The particle density was determined by the gas displacement method (Flint and Flint, 2002), with a helium gas pycnometer.

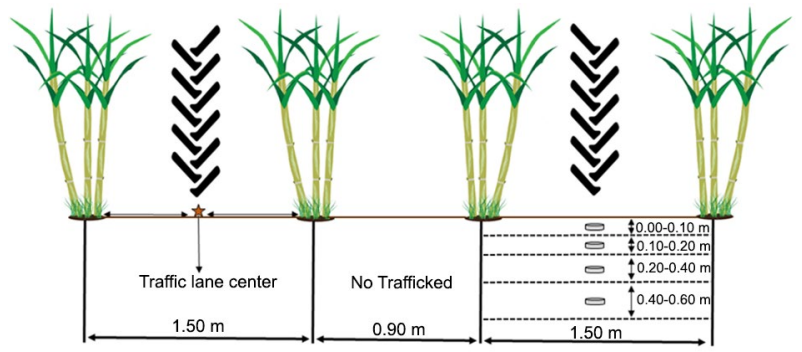

Figure 1 - Sampling scheme of undisturbed soil samples and sugarcane spacing in this experiment in both soil tillage treatments: conventional tillage (CT) and deep strip-tillage (DST). 
For the uniaxial compaction test, undisturbed samples were prepared and saturated by capillarity on a tray with water height corresponding to two thirds of the cylinder for $48 \mathrm{~h}$ and then subjected to different matric potentials $(-2,-10,-30,-100$ and $-500 \mathrm{kPa})$, thus obtaining different volumetric soil water content $\left(\theta_{\text {vol }}\right)$, as a result of three replicates per potential. Matric potentials -2 and $-10 \mathrm{kPa}$ were obtained by a suction table (Dane and Hopmans, 2002), and the other suctions by Richards membrane-plate extractor (Klute, 1986). After hydraulic equilibrium was established, each sample was weighed and subjected to the uniaxial compression test under normal stresses $(12.5,25,50,100,150,200,300$, $400,600,800$, and $1000 \mathrm{kPa}$ ), where each pressure was applied until $90 \%$ of de maximum deformation (Taylor, 1948), using a pneumatic consolidometer described by Figueiredo et al. (2011). Thereafter, the samples were oven-dried at $-/+105^{\circ} \mathrm{C}$ for $48 \mathrm{~h}$ to determine bulk density (BD) (Blake and Hartge, 1986) and water content.

The variation in soil sample height under the load applied was recorded and used in the soil strain calculations. From the values of soil displacement in the uniaxial compression test, void indices were calculated for each pressure applied, using the equation proposed by McBride and Joosse (1996).

For each sample, 12 pairs of vacuum index and pressure values applied were used to build the compression curve by the Gompertz equation (1825), as suggested by Gregory et al. (2006), fitted by the least squares method.

The preconsolidation pressure $\left(\sigma_{p}\right)$ was determined as the pressure of maximum curvature of the compression curve by the model proposed by Gregory et al. (2006) and described by Keller et al. (2011).

To elaborate soil load bearing capacity models (LBCM), preconsolidation pressure and water content were adjusted to the single exponential decay equation with two parameters proposed by Dias Junior and Pierce (1995), modified by Araujo-Junior et al. (2011) to volumetric soil water content $\left[\sigma_{p}=10^{(a+b \theta)}\right]$. This equation defines the load bearing capacity model, where $\sigma_{p}$ is preconsolidation pressure, $\theta$ is the volumetric water content and "a" and " $b$ " are adjusted parameters.

Sugarcane was harvested on Oct 2014 and Sept 2015 , at a soil water content volumetric $\left(\theta_{\text {vol }}\right)$ of $0.25 \mathrm{~m}^{3}$ $\mathrm{m}^{-3}$ and $0.31 \mathrm{~m}^{3} \mathrm{~m}^{-3}$. For this operation, the following machines was used: a harvester, with $263 \mathrm{~kW}$ and a tractor, with $134 \mathrm{~kW}$, pulling a trailer (Table 1).

After harvesting, undisturbed soil was also collected in stainless steel cylinders (diameter $69 \mathrm{~mm} \times$ height $25 \mathrm{~mm})$. The capillarity of these undisturbed samples was saturated with distilled water and equilibrated at potentials $-10,-100$ and $-400 \mathrm{kPa}$. The $\sigma_{\mathrm{p}}$ values, as described above, were plotted on LBCM and divided into three "regions" (Figure 2): points in region "a" indicate additional compaction; in region " $\mathrm{b}$ ", no additional soil compaction, but tends to occur if the load bearing capacity of the soil is not respected; and in region "c", no soil compaction, as suggested by Dias Junior et al. (2005).

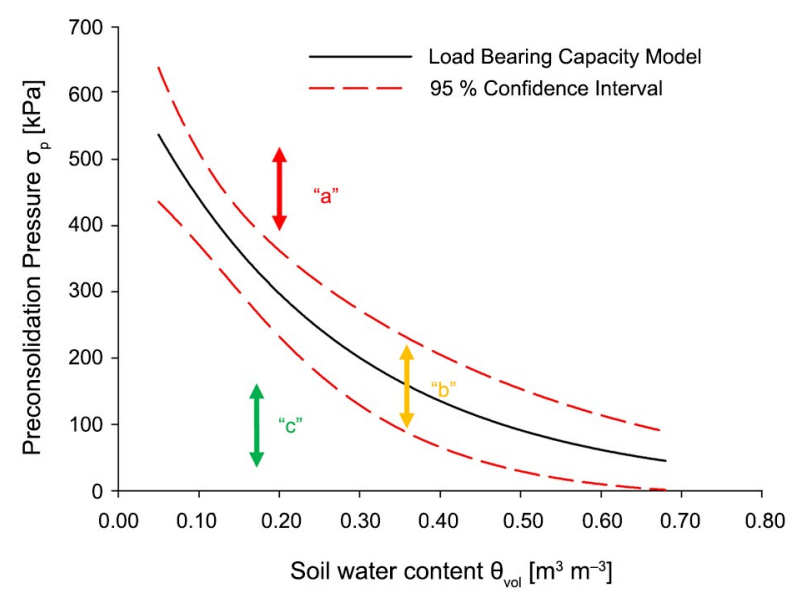

Figure 2 - Criteria used to analyze the effect of sugarcane harvesting on preconsolidation pressure of the Rhodic Nitisol. The regions considered are "a" region with soil compaction, "b" region did not suffer soil compaction, but with a tendency to compact, and "c" region without soil compaction. Adapted from Dias Junior et al. (2005).

\section{Statistical analysis}

The regression analyses of the compressibility test were performed using software SigmaPlot, version 12.0 (Jandel Scientific) and models were compared by the homogeneity test of linear models, as described by Snedecor and Cochran (1989). To obtain the linear models from the exponential model $\left[\sigma_{\mathrm{p}}=10^{(\mathrm{a}+\mathrm{b} \theta)}\right]$, logarithm was applied to the preconsolidation pressure values, resulting in the equation: $\log \sigma_{\mathrm{p}}=\mathrm{a}+\mathrm{b} \theta$. The homogeneity test of linear models considers two models, which are compared by the analysis of intercept "a", angular coefficient "b" and data homogeneity (F).

\section{Results and Discussion}

Load bearing capacity models (LBCM) $\left[\sigma_{p}=\right.$ $\left.10^{(\mathrm{a}+\mathrm{b} \theta)}\right]$ resulted in intercept values of linearized regression (a) between 3.48 and 5.05 and angular coefficient of linearized regression (b) between -3.20 and -9.07 . Coefficients $\left(\mathrm{R}^{2}\right)$ were significant at $p<0.01$ and ranged from 0.56 to 0.77 .

For the layers $0-0.10 \mathrm{~m}, 0.10-0.20 \mathrm{~m}, 0.20-0.40$, and $0.40-0.60 \mathrm{~m}, \mathrm{LBCM}$ were compared within each soil tillage (Table 2). For the deep strip-tillage (DST), LBCM were different in each layer studied. Under CT, however, regression equations between $\sigma_{p}$ and $\theta_{\text {vol }}$ were homogeneous for $0.10-0.20 \mathrm{~m}$ and $0.20-0.40 \mathrm{~m}$ layers, indicating similar models of soil load bearing capacity.

Therefore, a new fitting was carried out considering all values of preconsolidation pressure $\left(\sigma_{\mathrm{p}}\right)$ and volumetric moisture $\left(\theta_{\text {vol }}\right)$ of the layers $0.10-0.20 \mathrm{~m}$ and $0.20-0.40 \mathrm{~m}$ (Table 2). This new model was considered to represent the structural behavior of the two layers.

Regardless of the soil tillage method (CT or DST), layer $0.00-0.10 \mathrm{~m}$ had the lowest load bearing capacity 
(LBC) for the entire moisture range (Figure 3). This was associated with soil disturbance that causes aggregate breakage, negatively affecting the mechanical resistance of soil structure.

LBCM indicate a higher load bearing capacity at layers $0.10-0.20$ and $0.20-0.40 \mathrm{~m}$ (Figure 3 ) under both tillage systems. Moreover, the $\sigma_{p}$ values indicate the current state of soil compaction. The cumulative load effect of the soil tillage implements used and the previous traffic in the area probably created the so-called plow pan. The high pressure on the soil by the heavy disc harrows can cause compact subsurface layers and higher soil density increases friction or cohesion forces and the number of contact points between soil particles, resulting in a higher LBC (Oliveira et al., 2003). In Ferralsols cultivated with CT sugarcane after three harvests, Vischi Filho et al. (2015) found soil compaction under the traffic lane to a depth of $0.30 \mathrm{~m}$.

At layer $0.40-0.60 \mathrm{~m}$, the intermediate pattern of LBC may be explained because the load of agricultural machinery had no influence before sugarcane harvest. Possibly, the formation of the plow pan at layers 0.100.20 and $0.20-0.40 \mathrm{~m}$ acted as a physical barrier against the transmission of vertical stress, preventing stress from spreading to deeper soil layers, keeping it concentrated at the top layers, corroborating results reported by other studies (Horn, 2003; Boizard et al., 2013; Keller et al., 2014; Keller et al., 2016). The soil structure type may have also had an influence, since the structure in this layer is granular and in blocks in the upper layers.

Under conventional tillage (CT), LBC decreases in the traffic lane in the following order: layer 0.10-0.20 $\mathrm{m}=0.20-0.40 \mathrm{~m}>0.40-0.60 \mathrm{~m}>0.00-0.10 \mathrm{~m}$. Under deep strip-tillage (DST), LBC in layer 0.00-0.10 m was the lowest for the entire moisture range (Figure 4B), demonstrating that this layer is the most sensitive to soil compaction in this treatment.

The $\sigma_{p}$ values of layer $0.10-0.20 \mathrm{~m}$ under DST were higher than in the other layers, for water contents $\left(\theta_{\mathrm{vol}}\right)$ exceeding $0.31 \mathrm{~m}^{3} \mathrm{~m}^{-3}$. This may be associated with the fact that the experimental area was managed under longstanding CT. The negative effects on soil structure due to the intensive use of disc harrow has already been explained.

In water contents $\left(\theta_{\text {vol }}\right)$ lower than $0.31 \mathrm{~m}^{3} \mathrm{~m}^{-3}$, the preconsolidation pressure at layer $0.20-0.40 \mathrm{~m}$ was high-

Table 2 - Significance test ${ }^{1}$ between preconsolidation models ${ }^{2}$ in a Rhodic Nitisol within each soil tillage system.

\begin{tabular}{|c|c|c|c|c|}
\hline \multirow{2}{*}{ Soil tillage systems } & \multirow{2}{*}{ Layers (m) } & \multirow{2}{*}{$\mathrm{F}$} & \multicolumn{2}{|c|}{$\mathrm{F}$} \\
\hline & & & Angular coefficient, b & Linear coefficient, a \\
\hline \multirow{6}{*}{ Conventional Tillage } & $0.00-0.10$ vs $0.10-0.20$ & $\mathrm{H}$ & * & $\star \star$ \\
\hline & $0.00-0.10$ vs $0.20-0.40$ & $\mathrm{H}$ & ns & ** \\
\hline & $0.00-0.10$ vs $0.40-0.60$ & $\mathrm{H}$ & ns & * * \\
\hline & $0.10-0.20$ vs $0.20-0.40$ & $\mathrm{H}$ & ns & ns \\
\hline & $0.10-0.20+0.20-0.40$ vs $0.40-0.60$ & $\mathrm{NH}$ & ns & * \\
\hline & $0.10-0.20+0.20-0.40$ vs $0.00-0.10$ & $\mathrm{H}$ & * & ** \\
\hline \multirow{6}{*}{ Deep Strip-Tillage } & $0.00-0.10$ vs $0.10-0.20$ & $\mathrm{NH}$ & ns & * * \\
\hline & $0.00-0.10$ vs $0.20-0.40$ & $\mathrm{H}$ & ns & ** \\
\hline & $0.00-0.10$ vs $0.40-0.60$ & $\mathrm{H}$ & ns & * * \\
\hline & $0.10-0.20$ vs $0.20-0.40$ & $\mathrm{NH}$ & ns & ns \\
\hline & $0.10-0.20$ vs $0.40-0.60$ & $\mathrm{H}$ & ns & * * \\
\hline & $0.20-0.40$ vs $0.40-0.60$ & $\mathrm{H}$ & ns & ** \\
\hline
\end{tabular}

${ }^{1}$ Analysis according to Snedecor and Cochran (1989). ${ }^{2} \sigma_{\mathrm{f}}=10^{(\mathrm{a}+\mathrm{b} \theta)} ; \mathrm{F}=\mathrm{F}$ test for homogeneity of variance and for the adjusted regression parameters; $\mathrm{NH}=\mathrm{Non}-$ Homogeneous; $\mathrm{H}=$ Homogeneous; ${ }^{*} \mathrm{p}<0.05 ;{ }^{*} \mathrm{p}<0.01 ; \mathrm{ns}=$ non-significant.

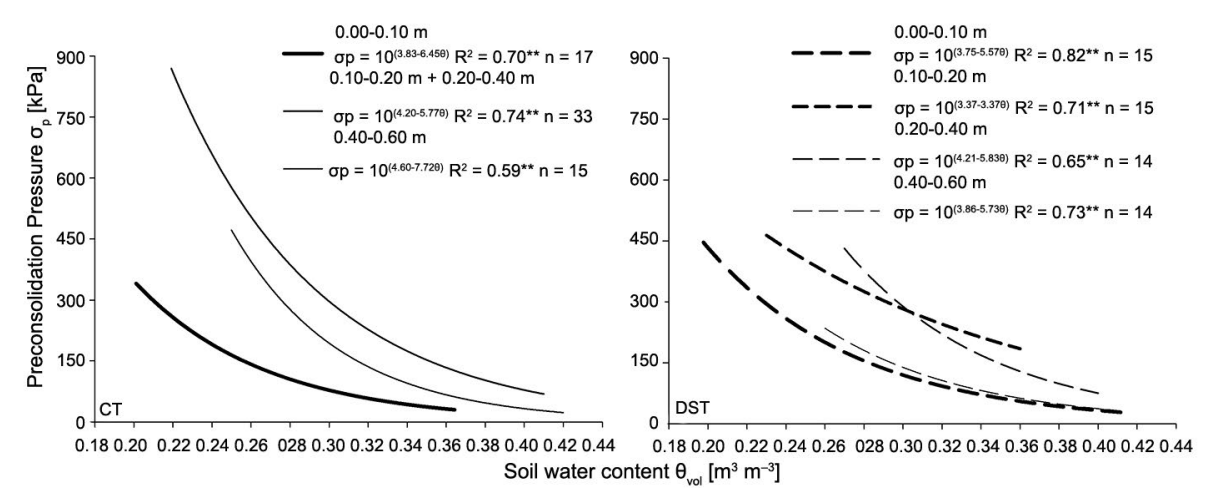

Figure 3 - Load bearing capacity models for Rhodic Nitisol in the traffic lane under Conventional Tillage (CT) and Deep Strip-Tillage (DST). 


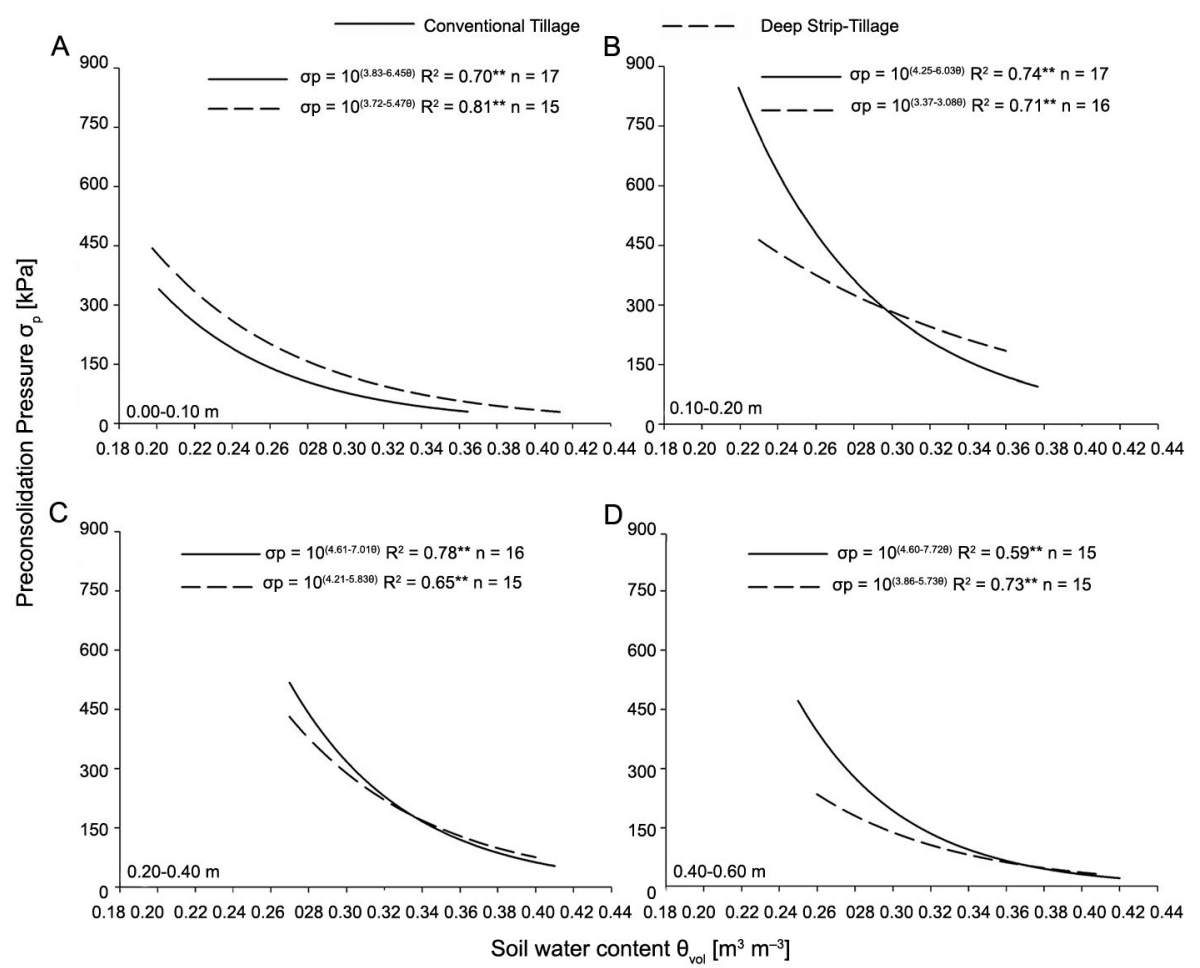

Figure 4 - Load bearing capacity models for Rhodic Nitisol in traffic lane under different soil tillage systems, at layers $0.00-0.10 \mathrm{~m}(\mathrm{~A}), 0.10-0.20$ $m(B), 0.20-0.40 \mathrm{~m}(\mathrm{C})$ and 0.40-0.60 (D) in Piracicaba (state of São Paulo).

Table 3 - Significance test ${ }^{1}$ between the preconsolidation models ${ }^{2}$ for Rhodic Nitisol under soil tillage systems at four layers.

\begin{tabular}{|c|c|c|c|}
\hline \multirow{2}{*}{ Soil tillage systems } & & \multicolumn{2}{|l|}{$F$} \\
\hline & $r$ & Angular coefficient $b$ & coefficient a \\
\hline & \multicolumn{3}{|c|}{ Layer $0.00-0.10 \mathrm{~m}$} \\
\hline \multirow[t]{2}{*}{$\begin{array}{l}\text { Conventional Tillage vs } \\
\text { Deep Strip-Tillage }\end{array}$} & $\mathrm{H}$ & ns & ** \\
\hline & \multicolumn{3}{|c|}{ Layer 0.10-0.20 m } \\
\hline \multirow[t]{2}{*}{$\begin{array}{l}\text { Conventional Tillage vs } \\
\text { Deep Strip-Tillage }\end{array}$} & $\mathrm{NH}$ & ** & ns \\
\hline & \multicolumn{3}{|c|}{ Layer $0.20-0.40 \mathrm{~m}$} \\
\hline \multirow[t]{2}{*}{$\begin{array}{l}\text { Conventional Tillage vs } \\
\text { Deep Strip-Tillage }\end{array}$} & $\mathrm{H}$ & * & ns \\
\hline & \multicolumn{3}{|c|}{ Layer $0.40-0.60 \mathrm{~m}$} \\
\hline $\begin{array}{l}\text { Conventional Tillage vs } \\
\text { Deep Strip-Tillage }\end{array}$ & $\mathrm{NH}$ & ns & ns \\
\hline
\end{tabular}

er than in the other layers. This reflects the history of DST stresses, since the load applied by agricultural machines used in harvesting under this soil tillage caused higher compaction at this layer, conferring a greater resistance to compression.

At all soil layers, the significance test indicated that the management systems presented significant difference of LBCM, either by difference $(p<0.05$ or $p<$
0.01) in the angular coefficient, linear coefficient or in homogeneity (Table 3).

A higher LBC of the Rhodic Nitisol was observed under DST across the entire moisture range (Figure 4A). This result is probably due to the higher initial bulk density (BD) values under DST since it was not previously prepared at the time of cane planting (experiment installation). At the surface layer of Ferralsol, Oliveira et al. (2003) found that the soil of tilled areas had lower LBC than in areas without tillage.

In addition to the initial soil tillage, another factor that may have contributed to increase compaction at the surface layer under DST is associated to the type of machinery used in this treatment: a tractor $107.9 \mathrm{kN}$ weight coupled to a tractor drawbar an implement 19.6 $\mathrm{kN}$ weight. This higher load, both on the front and rear axles, promoted a higher soil stress to the surface layer in DST than under CT, where a tractor $58.9 \mathrm{kN}$ weight was used. The tractor used in DST applied to the soil $1,113 \mathrm{kPa}$ of mean contact pressure (MCP) for the rear axle and $1,106 \mathrm{kPa}$ for front axle, whereas the tractor used in CT applied $690 \mathrm{kPa}$ and $590 \mathrm{kPa}$ MCP for rear and front axle respectively.

At layer 0.10-0.20 m under DST, LBC was higher at moisture levels above $0.29 \mathrm{~m}^{3} \mathrm{~m}^{-3}$ (Figure 4B), demonstrating more resistance to compaction at higher moisture levels compared to CT. Traffic lane in DST was not tilled and this probably kept cohesion between soil particles and stable soil aggregates (Soane, 1990), mak- 
ing the soil less susceptible to compaction. At moisture levels lower than $0.29 \mathrm{~m}^{3} \mathrm{~m}^{-3}$, the higher LBC in CT is associated to negative effects on soil structure due to the intensive disc harrow use, promoting greater soil compaction.

For layers $0.20-0.40 \mathrm{~m}$ and $0.40-0.60 \mathrm{~m}$, the differences in LBCM between the soil tillage systems (Figures $4 \mathrm{C}$ and $4 \mathrm{D}$ ), indicated higher LBC under CT than DST for volumetric moisture levels below $0.33 \mathrm{~m}^{3} \mathrm{~m}^{-3}$ and $0.36 \mathrm{~m}^{3} \mathrm{~m}^{-3}$ respectively, for layers $0.20-0.40 \mathrm{~m}$ and 0.40-0.60 m. At higher moisture levels, the pattern was similar for both tillage systems.

Soils with higher mechanical strength may be beneficial for agricultural traffic. On the other hand, this feature may limit root growth and negatively influence the flow of air, water and nutrients in the soil (Alaoui and Helbling, 2006).

Impacts of mechanical harvesting of sugarcane show that $33 \%$ of samples from the surface layer of traffic lane under $\mathrm{CT}$, after the first harvest, tended to additional compaction if LBC was exceeded and 67 $\%$ showed no signs of compaction (Dias Junior et al., 2005). In contrast, after the second harvest, additional soil compaction was detected in $100 \%$ of the samples (Figure 5A).

In DST traffic lanes, additional compaction was observed in only $8 \%$ of the collected samples detected after the first harvest, and $25 \%$ of samples tended to increase compaction under excessive LBC values (Region " $b$ " Figure 5B). After the second harvest, there was a $17 \%$ increase in the samples that tended to compaction. The increase in compaction under CT in layer 0.00$0.10 \mathrm{~m}$ is due to lower LBC than under DST, caused by disc harrow of the entire area at tillage, highlighting the stress history in this management.

The increase in pressure values of LBC from first to second harvesting seasons were influenced by water content at harvesting (Figures 5A-G). There was a reduction in LBC from $165 \mathrm{kPa}$ to $68 \mathrm{kPa}$ under CT and from $230 \mathrm{kPa}$ to $108 \mathrm{kPa}$ under DST, for the same surface layer $(0.00-0.10 \mathrm{~m})$, with increasing moisture levels at harvest from $0.25 \mathrm{~m}^{3} \mathrm{~m}^{-3}$ in the $2014 / 15$ to $0.31 \mathrm{~m}^{3} \mathrm{~m}^{-3}$ in the 2015/16 growing season (Figures 5A and $5 B$ ). Other authors also reported a reduction in preconsolidation pressure at higher soil moisture (Severiano et al., 2010; Vischi Filho et al., 2015).

From the total CT samples of layer $0.10-0.20 \mathrm{~m}$ in the $2014 / 15$ growing season, only $17 \%$ was plotted in region "a" with additional soil compaction (Figure 5C). The following year presented an increase of approximately $25 \%$ in samples with additional compaction. At both harvests (2014/15 and 2015/16), $25 \%$ of the samples were grouped in region " $b$ " with tendency to acquire additional soil compaction. There was a $23 \%$ reduction in the samples concentrated in the region with no compaction (region " $\mathrm{c}$ ").

For DST (Figure 5B), no additional soil compaction was detected in $100 \%$ of the samples and most analyzed samples representing the two growing seasons 2014/15 and 2015/16 were classified in region "c".

The presence of a layer with a high LBC (0.10$0.20 \mathrm{~m}$ ) in DST (Figure 5D) may have interfered with stress distribution in the deeper soil layers, due to the differences in the Young's modulus between the soil layers. According to Keller et al. (2014), differences in the Young's modulus between soil layers may be due to variations in soil texture, soil organic matter, bulk density, and matrix potential. The authors reported that, unfortunately, very little is known about the Young's modulus in different layers and how it is related to soil texture, soil structure and soil moisture, despite the large number of data on compression curves reported in the literature. The Young's modulus or the elastic modulus is a stiffness measure of a solid material and defines the relationship between stress and strain in the soil.

Samples of layer 0.20-0.40 m under CT were classified mostly as no compacted (Region "c" in Figure 5E), for both harvests. There is a trend to compaction if soil LBC is not respected at $17 \%$ and $33 \%$, in 2014/15 and $2015 / 16$, respectively, soil compaction and was observed in the remaining $17 \%$ of CT samples (Region "a").

DST samples in layer 0.20-0.40 m (Figure 5F) were in region "c", except for the second harvest, when $8 \%$ of the observed samples had additional compaction. At deeper layers (0.40-0.60 m) (Figures 5G and 5H), LBCM behavior and impacts on soil structure were similar and only $8 \%$ of the samples evaluated presented additional soil compaction after the ratoon cane harvest (2015/16 harvest).

The results show a greater soil structure degradation at surface $(0.00-0.20 \mathrm{~m})$ under CT after two sugarcane harvests. These results corroborate Severiano et al. (2010) in an evaluation of compaction in two soil types (Ferralsol and Cambisol) under a CT system in sugarcane, where a compacted soil layer was detected above depth $0.30 \mathrm{~m}$. These results suggest that, in the coming years, LBC must be taken into account to drive agricultural machines in these systems, particularly on crop harvesting. Otherwise, the soil preconsolidation pressure will be exceeded, resulting in additional compaction.

Moreover, in the first year (2014/15 harvest), regardless of the soil tillage, there was no occurrence of soil compaction, associated with low water content at the moment of mechanical harvest. However, in the second year of mechanical harvest, signs of deep soil compaction begin to appear. This concerns, according to Chamen et al. (2003), since the removal of subsoil compaction is costly and time demanding. According to Arvidsson and Keller (2007), the depth of vertical stress distribution in soil is determined mainly by the wheel load.

The use of LBC models suggest that the maximum wheel load is a practical, sustainable way of preventing deleterious effects on the physical, chemical or biologi- 


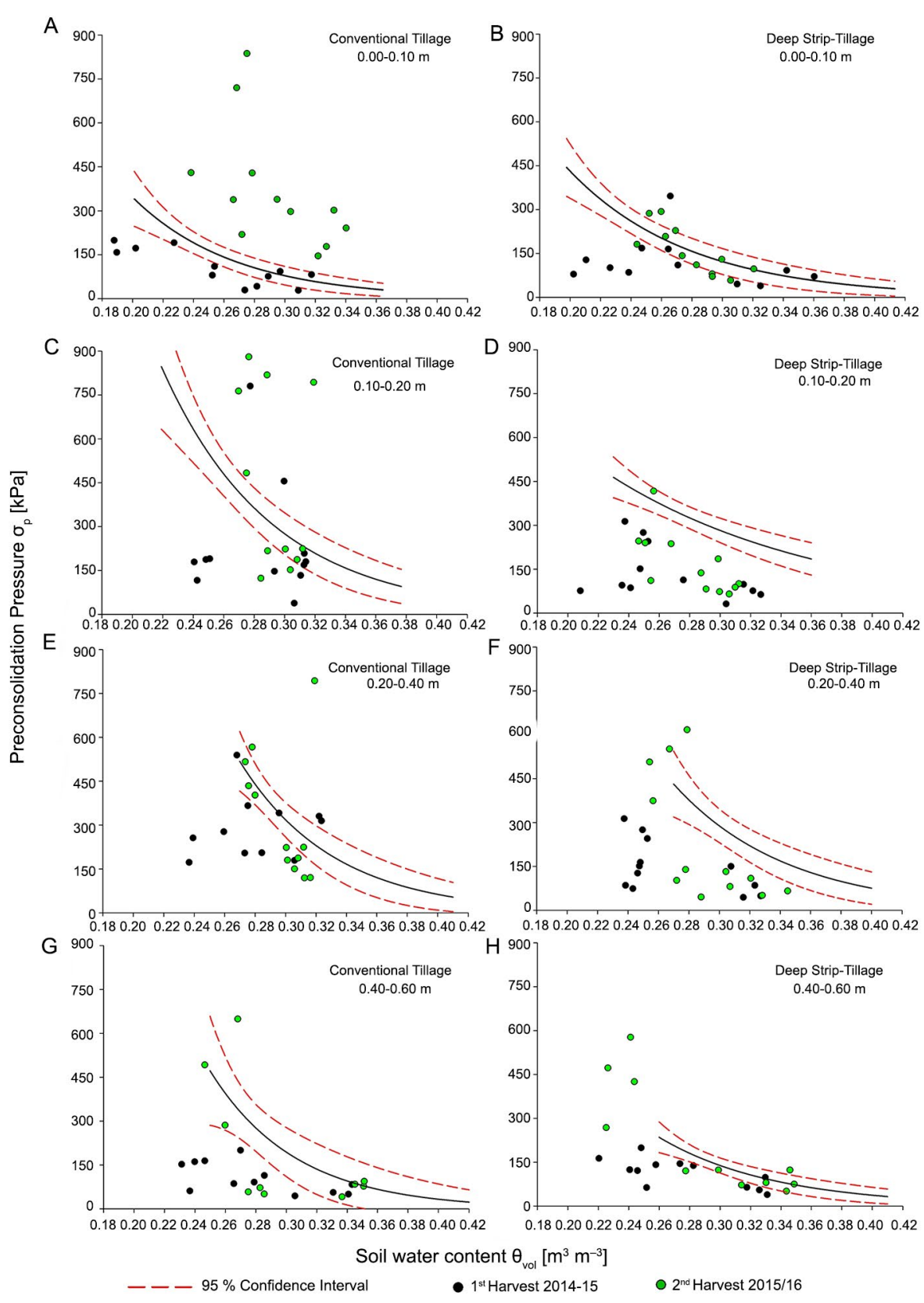

Figure 5 - Load bearing capacity models describing the impact of the mechanized harvesting on the sugarcane in a Rhodic Nitisol under different soil tillage systems, at layers 0.00-0.10 m (A, B), 0.10-0.20 m (C, D), 0.20-0.40 m (E, F) and 0.40-0.60 (G, H) in Piracicaba (state of São Paulo). $\mathrm{CT}=$ Conventional Tillage; DST $=$ Deep Strip-Tillage.

cal functions of the soil. LBCM predict the maximum soil load can bear at different moisture content, without causing additional compaction. Considering that the preconsolidation pressure is an indicator of maximum pressure that could be applied to the soil to prevent compaction additional, studies on soil compressibility could support decision on whether or not carry out a mechanized agricultural operation, or whether or not to use machinery traffic in the area.
According to Severiano et al. (2010), the adoption of preventive measures to avoid additional soil compaction by mechanical sugarcane harvesting is recommended, including the control of pressure level per axle of the machine (Bennett et al., 2015), as well as, control of the inflating pressure of tires and increasing the number of axles of trailers, reducing thus the load applied on soil by the machine. Traffic over crop residues has also been suggested as a preven- 
tive measure, in addition to monitoring soil moisture to perform agricultural driving at moisture contents below the limit (Silva et al., 2016). These preventive traffic control measures (Sousa et al., 2017) may be a promising alternative to avoid the spread of soil compaction throughout the entire sugarcane cultivation area.

\section{Conclusions}

The soil stress history was remained in subsoil layers and the load support capacity of the soil in the traffic lanes was higher under deep strip-tillage. Tillage operations performed across the entire area did not reduce the stress history in the traffic lanes, on the contrary, it accumulated more pressure under conventional tillage.

At surface soil layer, the impacts of sugarcane harvesting were minimized by the high state of initial compaction in the deep strip-tillage. In contrast, under conventional tillage, sugarcane mechanical harvest promoted additional soil compaction in traffic lanes after the second crop.

Soil water content during mechanical harvesting was a relevant factor to maximize impacts on the soil structure in the traffic lanes.

\section{Acknowledgements}

The authors are grateful the Fundação de Amparo à Pesquisa do Estado de São Paulo (FAPESP) (Grants \# 2014/07434-9; 2013/10427-1; 2013/21687-4) and Coordenação de Aperfeiçoamento de Pessoal de Nível Superior (CAPES). They also wish to thank the researchers Drs. Fábio Luis Ferreira Dias and Raffaella Rossetto of the Agência Paulista de Tecnologia dos Agronegócios (APTA) - Centro Sul for conceding access and support to field study.

\section{Authors' Contributions}

Conceptualization: Guimarães Júnnyor, W.S.; De Maria, I.C.; Dechen, S.C.F. Data acquisition: Guimarães Júnnyor, W.S.; Lima, C.C. Data analysis: Guimarães Júnnyor, W.S.; De Maria, I.C.; Araujo-Junior, C.A. Design of Methodology: Guimarães Júnnyor, W.S.; Figueiredo, G.C.; Vitti, A.C. Writing and editing: Guimarães Júnnyor, W.S.; De Maria, I.C.; Araujo-Junior, C.A.

\section{References}

Alaoui, A.; Helbling, A. 2006. Evaluation of soil compaction using hydrodynamic water content variation: comparison between compacted and non-compacted Soil. Geoderma 134: 97-108.

Alvares, C.A.; Stape, J.L.; Sentelhas P.C.; Gonçalves, J.L.M.; Sparovek, G. 2013. Köppen's climate classification map for Brazil. Meteorologische Zeitschrift 22: 711-728.
Araujo-Junior, C.F.; Dias Junior, M.S.; Guimarães, P.T.G.; Alcântara, E.N. 2011. Load bearing capacity and critical water content of a Latossol induced by different managements. Revista Brasileira de Ciência do Solo 35: 115-31 (in Portuguese, with abstract in English).

Arvidsson, J.; Keller, T. 2007. Soil stress as affected by wheel load and tyre inflation pressure. Soil and Tillage Research 96: 284291.

Bennett, J.M.; Woodhouse, N.P.; Keller, T.; Jensen, T.A.; Antille, D.L. 2015. Advances in cotton harvesting technology: a review and implications for the John Deere round baler cotton picker. Journal of Cotton Science 19: 225-249.

Blake, G.R.; Hartge, K.H. 1986. Bulk density. p. 363-375. In: Klute, A., ed. Methods of soil analysis. Part 1. Physical and mineralogical methods. 2ed. American Society of Agronomy, Madison, WI, USA.

Boizard, H.; Yoon, S.W.; Leonard, J.; Lheureux, S.; Cousin, I.; Roger-Estrade, J.; Richard, G. 2013. Using a morphological approach to evaluate the effect of traffic and weather conditions on the structure of a loamy soil in reduced tillage. Soil and Tillage Research 127: 34-44.

Centro de Pesquisas Meteorológicas e Climáticas aplicadas a Agricultura [CEPAGRI]. 2018. Climate of the municipality of São Paulo = Clima dos municípios paulistas. Available at: http://www.cpa.unicamp.br/outras-informacoes/clima muni_436.html [Accessed Apr 23, 2018] (in Portuguese).

Chamen, W.T.C.; Alakukku, L.; Pires, S.; Sommerd, C.; Spoor, G.; Tijink, F.; Weisskop, P. 2003. Prevention strategies for field traffic-induced subsoil compaction: a review. Part 2. Equipment and field practices. Soil and Tillage Research 73: 161-174.

Companhia Nacional de Abastecimento. [CONAB]. 2018. Followup of the Brazilian sugarcane harvest, 2017/18 harvest: fourth lifting = Acompanhamento da safra brasileira de cana-deaçúcar, safra 2017/18: quarto levantamento. CONAB, Brasília, DF, Brazil. Available at: http://www.conab.gov.br [Accessed May 8, 2018] (in Portuguese).

Dane, J.H.; Hopmans, J.W. 2002. Water retention and storage. p. 671-720. In: Dane, J.H.; Topp, G.C., eds. Methods of soil analysis. Part 4. Physical methods. Soil Science Society of America, Madison, WI, USA. (SSSA Book Series).

Dias Junior, M.S.; Leite, F.P.; Lasmar Júnior, E.; Araujo-Júnior, C.F. 2005. Traffic effects on the soil preconsolidation pressure due to eucalyptus harvest operations. Scientia Agricola 62: 248-255.

Dias Junior, M.S.; Pierce, F.J. 1995. A simple procedure for estimating preconsolidation pressure from soil compression curves. Soil Technology 8: 139-151.

Figueiredo, G.C.; Silva, A.P.; Tormena, C.A.; Giarola, N.F.B.; Moraes, S.O.; Almeida, B.G. 2011. Development of a pneumatic consolidometer: compaction modeling, penetrometry and tensile strength of soil aggregates. Revista Brasileira de Ciência do Solo 35: $389-402$ (in Portuguese, with abstract in English).

Flint, A.L.; Flint, L.E. 2002. Particle density. p. 229-240. In: Dane, J.H.; Topp, G.C., eds. Methods of soil analysis. Part 4. Physical methods. Soil Science Society of America, Madison, WI, USA. (SSSA Book Series).

Gee, G.W.; Bauder, J.W. 1986. Particle-size analysis. p. 383-411. In: Klute, A., ed. Methods of soil analysis. 2ed. American Society of Agronomy, Madison, WI, USA. 
Gompertz, B. 1825. On the nature of the function expressive of the law of human mortality, and on a new mode of determining the value of life contingencies. Philosophical Transactions of the Royal Society of London 115: 513-583.

Gregory, A.S.; Whalley, W.R.; Watts, C.W.; Bird, N.R.A.; Hallett, P.D.; Whitmore, A.P. 2006. Calculation of the compression index and precompression stress from soil compression test data. Soil and Tillage Research 89: 45-57.

Horn, R. 2003. Stress-strain effects in structured unsaturated soils on coupled mechanical and hydraulic processes. Geoderma 116: 77-88.

IUSS Working Group. 2015. World Reference Base for Soil Resources 2014: International Soil Classification System for Naming Soils and Creating Legends for soil maps. FAO, Rome, Italy.

Keller, T.; Lamandé, M.; Schjønning, P.; Dexter, A.R. 2011. Analysis of soil compression curves from uniaxial confined compression tests. Geoderma 163: 13-23.

Keller, T.; Lamande, M.; Arvidsson, J.; Berli, M.; Ruiz, S.; Schjonning, P.; Selvadurai A.P.S. 2014. Transmission of vertical soil stress under agricultural tyres: comparing measurements with simulations. Soil and Tillage Research 140: 106-117.

Keller, T.; Ruiz, S.; Arvidsson, J.; Stettler, M.; Berli, M. 2016. Determining soil stress beneath a tire: measurements and simulations. Soil Science Society of America Journal 80: 541553.

Klute, A. 1986. Water retention: laboratory methods. In: Klute, A., ed. Methods of Soil Analysis. 2ed. American Society of Agronomy, Madison, WI, USA.

Lozano, N.; Rolim, M.M.; Oliveira, V.S.; Tavares, U.E.; Pedrosa, E.M.R. 2013. Evaluation of soil compaction by modeling field vehicle traffic with SoilFlex during sugarcane harvest. Soil and Tillage Research 129: 61-68.

McBride, R.A.; Joosse, P.J. 1996. Over consolidation in agricultural soils. II. Pedotransfer functions for estimating preconsolidation stress. Soil Science Society of America Journal 60: 373-380.

Oliveira, G.C.; Dias Júnior, M.S.; Resck, D.V.S.; Curi, N. 2003. Structural changes and compressive behavior of a dystrophic clayey Red Latosol under different use and management systems. Pesquisa Agropecuária Brasileira 38: 291-299 (in Portuguese, with abstract in English).
Reichert, J.M.; Suzuki, L.E.A.S.; Reinert, D.J.; Horn, R.; Håkansson, I. 2009. Reference bulk density and critical degreeof-compactness for no-till crop production in subtropical highly weathered soils. Soil and Tillage Research 102: 242-54.

Severiano, E.C.; Oliveira, G.C.; Dias Júnior, M.S.; Castro, M.B.; Oliveira, L.C.; Costa, K.A.P. 2010. Compaction of soils cultivated with sugarcane. I. Modeling and quantification of the additional soil compaction after harvest operations. Engenharia Agrícola 30: 404-413 (in Portuguese, with abstract in English).

Silva, R.B.D.; Iori, P.; Souza, Z.M.D.; Pereira, D.D.M.G.; Vischi Filho, O.J.; Silva, F.A.D.M. 2016. Contact pressures and the impact of farm equipment on Latosol with the presence and absence of sugarcane straw. Ciência e Agrotecnologia 40: 265278.

Snedecor, G.W.; Cochran, W.G. 1989. Statistical methods. 8ed. Iowa State University Press, Ames, IA, USA.

Soane, B.D. 1990. The role of organic matter in soil compatibility: a review of some practical aspects. Soil and Tillage Research 16: 179-201.

Sousa, A.C.M.; Souza, Z.M.; Claret, R.M.P.; Torres, J.L.R. 2017. Traffic control with autopilot as an alternative to decrease soil compaction in sugarcane areas. Tropical and Subtropical Agroecosystems 20: 173-182.

Souza, G.S.; Souza, Z.M.; Silva, R.B.; Araújo, F.S.; Barbosa, R.S.; Araújo, F.S. 2014. Effects of traffic control on the soil physical quality and the cultivation of sugarcane. Revista Brasileira de Ciência do Solo 38: 135-146.

Taylor, D.M. 1948. Fundamentals of Soil Mechanics. John Wiley, New York, NY, USA.

Vischi Filho, O.J.; Souza, Z.M.; Silva, R.B.; Lima, C.C.; Pereira, D.M.G.; Lima, M.E.; Sousa, A.C.M.; Souza, G.S. 2015. Load support capacity of an Oxisol cultivated with sugarcane and mechanization effects on the soil. Pesquisa Agropecuária Brasileira 50: 322-332 (in Portuguese, with abstract in English). 